ISSN 1027-5495. Functional Materials, 23, No.4 (2016), p. 668-675

\title{
Screening of lignin-degrading fungi for their ability to decay cassava residue
}

\author{
Bin Xu, Huixing Li, Chaojun Du, Ying Wang, Bin Li \\ School of Biological and Chemical Engineering, \\ Nanyang Institute of Technology, Nanyang 473004, P.R. China
}

\section{Received July 22,2016}

\begin{abstract}
To screen applicable fungi for their ability to decay cassava residue, nineteen lignin-degrading fungi were isolated by guaiacol and azure B plates. Cassava residue decayed characteristics of the isolates were evaluated systematically by principal component analysis (PCA) of weight and components loss data, and compared with those of Phanerochaete chrysosporium and Trametes sp. SYBC-L4. Four groups of decayed cassava residue were identified. Fungus N1 and N3 grouped together and showed high lignin-degrading selectivity. Fungus N5 and N8 grouped with P. chrysosporium and showed high degradation ability. During the four weeks incubation, the lignin-degrading selectivity value of fungus N3 ranged from 1.14 to 1.38 and was the best, the weight loss of fungus N5 and N8 achieved $30.93 \%$ and $33.34 \%$, respectively. Fungus N3, N5, and N8 were identified as Pleurotus sp., Trametes sp. and Coriolopsis sp. based on 18S rDNA gene sequences, respectively. PCA is an effective method in recognizing cassava residue decayed characteristics of fungi and is helpful to screen fungi for their potential application. The three screened out fungi could be used to decay cassava residue for enhancement of its bioconversion efficiency.

Keywords: Lignin-degrading fungi, cassava residue, decay, principal component analysis, screening.
\end{abstract}

Исследованы девятнадцать грибов, разрушающих лигнин с целью разрушения отходов маниоки. Характеристики разрушенных отходов маниоки были оценены методом главных компонент (PCA) по данным потерь в весе и сравнивались с такими же характеристиками для Phanerochaete chrysosporium and Trametes sp. SYBC-L4. Были определены четыре группы грибов, разлагавших отходы маниоки. Грибы N1 и N3 были выделены в одну группу, и они показали высокую избирательность при разрушении лигнина. Грибы N5 и N8 были помещены в одну группу с $P$. chrysosporium и показали высокую способность к деградации лигнина. В течение четырех недель инкубации гриба N3 значение его лигнин разрушающей селективности было наилучшим и колебалось от 1,14 до 1,38 , потеря в весе для грибов N5 и N8 достигла 30,93\% и 33,34\%, соответственно. Грибы N3, N5 и N8 были идентифицированы как Pleurotus sp., Trametes sp. and Coriolopsis sp., основанные на генных последовательностях $18 \mathrm{~S}$ рекомбинантной ДНК, соответственно. РСА является әффективным методом в выявлении способности грибов к разрушению отходов маниоки. Установлено, что из подвергшихся скринингу образцов три гриба можно использовать для повышения әффективности биоконверсии отходов маниоки.

Скринінг грибів, що руйнують лігнін, на предмет їх здатності розкладати відходи маніоки. Бінь Сюй, Хуей Сін Лі, Чао Цзюнь Ду, Ін Ван, Бінь Лі

Досліджено дев'ятнадцять грибів, що руйнують лігнін з метою руйнування відходів маніоки. Характеристики зруйнованих відходів маніоки були оцінені систематичн о за допомогою методу головних компонент (PCA) за даними втрат у вазі і в компонентах, i порівнювалися $з$ такими ж характеристиками для Phanerochaete chrysosporium and Trametes $s p$. SYBC-L4. Були визначені чотири групи грибів, що розкладають відходи маніоки. Гриби N1 i N3 були виділені в одну групу, і вони показали високу вибірковість при руйнуванні 
лігніну. Гриби N5 і N8 були поміщені в одну групу з $P$. chrysosporium і показали високу здатність до деградації лігніну. Протягом чотирьох тижнів інкубації гриба N3 значення його лігнін руйнуе селективності було найкращим і коливалося від 1,14 до 1,38, втрата у вазі для грибів N5 і N8 досягла 30,93\% і 33,34\%, відповідно. Гриби N3, N5 і N8 були ідентифіковані як Pleurotus sp., Trametes sp. and Coriolopsis sp., засновані на генних послідовностей $18 \mathrm{~S}$ рекомбінантної ДНК, відповідно. РСА є ефективним методом у виявленні здатності грибів до руйнування відходів маніоки, він виявився корисним при проведенні скринінгу грибів 3 метою їх можливого застосування. Встановлено, що з зазнали скринінгу зразків три гриба можна використовувати для підвищення ефективності біоконверсії відходів маніоки.

\section{Introduction}

Cassava residue is a lignocellulosic waste, which is generated from cassava-based ethanol production [1]. Approximate 0.3 million tons (dry matter) of cassava residue are generated annually in China [2]. Handle of the waste is a problem and this problem will become increasing severe with increased industrial production of cassava-based ethanol. Direct discharge of cassava residue will cause serious environmental pollution and also be a huge waste of carbohydrate resources [3]. Currently, cassava residue is mainly used as raw material for production of methane or protein feed. However, the bioconversion efficiency of cassava residue is low due to its recalcitrant lignocellulose structure [1,4]. Hence, to improve the bioconversion efficiency of cassava residue, a promising method must be explored to decompose its lignocellulosic components, in particular the lignin component [5]. From the economic and environmental perspectives, fungal decay with lignin-degrading microorganisms has received great interest as an alternative to physical and chemical methods since it is a simple process and low energy requirement [6].

The application of fungal decay in various lignocellulosic biomass, e.g. wheat straw, rice straw, cotton stalks, and woody biomass have been reported [7-10]. The low lignin-degrading selectivity and long decay time are core problems associated with fungal decay. Therefore, fungi with high lignin-degrading selectivity and high degradation ability are preferred to be applied in lignocellulosic biomass decayed [11]. However, a fungal species does not exhibit the same characteristic to decay different lignocellulosic biomass and the fungal decay specificity has been reported [12]. As a consequence of the specificity, researchers cannot screen out a "universal" strain, and instead need to screen appropriate fungi to decay specific lignocellulosic biomass $[13,14]$.

To the best of our knowledge, there are no reports of fungal decay in cassava residue. Hence, the purpose of this study was to isolate lignin-degrading fungi that decay cassava residue with high lignin-degrading selectivity or high degradation ability. Moreover, to evaluate systematically cassava residue decayed characteristics of the isolates, principle components analysis (PCA) was applied since it has been proved to be a useful tool to extract important information from a large group of dataset $[12,15-17]$

\section{Materials and methods}

\subsection{Raw Material}

Cassava residue was obtained from the Yong Xiang Ethanol Co. Ltd., Wujiang, China. The raw material was dried at $105^{\circ} \mathrm{C}$ and milled to pass through 40-mesh screen. Cassava residue components were as follows: total organic carbon (TOC) $33.85 \pm 0.17 \%$; hemicellulose $10.49 \pm 0.70 \%$; lignin $20.19 \pm 0.22 \%$; cellulose $31.46 \pm 0.63 \%$.

\subsection{Fungal sources and sampling}

Eighty-two samples were collected from various places in China, including Wuxi, Hefei, Nanjing, Nanyang and Hangzhou. The isolates were obtained from various fruit bodies. Phanerochaete chrysosporium (CICC 40719) and Trametes sp. SYBC-L4 (NCBI accession number: HQ891288) were cultured for comparison with the isolates. $P$. chrysosporium was obtained from Beina Chuanglian Biological Research Institute, Trametes sp. SYBC-L4 was donated by Professor Liao, Jiangnan University, Wuxi.

\subsection{Isolation of lignin-degrading fungi}

Samples were cleaned using sterile water and then inoculated onto potato dextrose agar (PDA) plates containing $400 \mathrm{mg} / \mathrm{L}$ of guaiacol or $50 \mathrm{mg} / \mathrm{L}$ of azure B dye. Lignin-degrading fungi would make the guaiacol become red or azure B dye decolorization [18,19]. After ten days of incubation, isolates exhibiting diffusible guaiacol-reddening or azure B decolorization zone were lignin-degrading fungi.

\subsection{Genetic Analyses}

Fungal DNA was extracted from $100 \mathrm{mg}$ of mycelia grown on potato dextrose broth (PDB). Total DNA was extracted using a UNIQ-10 Fungal Genomic DNA Prep Kit (Sangon Biotech Co., Ltd., China) and following the manufacturer's instructions. 
Polymerase chain reaction (PCR) was performed in a $25 \mu \mathrm{L}$ reaction volume containing $1 \mu \mathrm{L}$ of template, $0.5 \mu \mathrm{L}$ dNTP $\operatorname{mix}(10 \mathrm{Mm}$ each), $0.2 \mathrm{uL}$ Taq $(5 \mu / \mu \mathrm{L}), 2.5 \mu \mathrm{L} 10^{*}$ Taq reaction buffer, and $0.5 \mu \mathrm{L}(10 \mu \mathrm{M})$ of each primer (NS1: 5'GTAGTCATATGCTTGTCTC 3', NS6: 5' GCATCACAGACCTGTTATTGCCTC 3'). The amplification program was consisted of an initial preheating for $5 \mathrm{~min}$ at $94{ }^{\circ} \mathrm{C}$, followed by 35 cycles of denaturation at $94{ }^{\circ} \mathrm{C}$ for $30 \mathrm{~s}$, annealing at $55^{\circ} \mathrm{C}$ for $35 \mathrm{~s}$, and extension at $72{ }^{\circ} \mathrm{C}$ for $1 \mathrm{~min}$, with a final extension of $72{ }^{\circ} \mathrm{C}$ for 8 min. The PCR products were separated in agarose $(1.5 \%, \mathrm{w} / \mathrm{v})$ gels using Tris-borate (TBE) buffer, and were directly sequenced by Sangon Biotech Co., Ltd (Shanghai, China). Sequences were subjected to BLAST searching using the National Center for Biotechnology Information (NCBI) database, and phylogenetic position was inferred $[8,19]$

\subsection{Fungal decay cassava residue}

Fungi were maintained on PDA plates at 4 ${ }^{\circ} \mathrm{C}$ and periodically subcultured. The fungal colonies were harvested from seven days old cultures that were grown on PDA plates. Cultivations were in $250-\mathrm{mL}$ Erlenmeyer flasks containing $10 \mathrm{~g}$ cassava residue, $25 \mathrm{~mL}$ distilled water, and four $10 \mathrm{~mm}$ agar plugs removed from the PDA plates. The flasks were incubated at $30{ }^{\circ} \mathrm{C}$ and humidity of $75 \%$ and shaken every three days. After harvesting, solid fractions were dried at $105{ }^{\circ} \mathrm{C}$ until the constant weight was obtained. Dry solids were then weighed and their content tested $[10,20]$.

\subsection{Determination of lignin, cellulose} and hemicellulose

Lignin, cellulose and hemicellulose were determined by Van Soest method [21]. The cellulose was considered the difference between the acid detergent fiber (ADF) and acid detergent lignin (ADL). Lignin was considered the difference between the ADL and ash content. The hemicellulose was considered the difference between neutral detergent fiber (NDF) and the $\mathrm{ADF}$.

The loss ratio (\%) of weight, lignin, cellulose and hemicellulose were calculated using the following equation (1):

$$
\text { Loss }(\%)=\left(m_{0}-m\right) / m_{0} \times 100 \%
$$

Where $m_{0}(g)$ is the initial weight of cassava residue or lignocellulosic components (lignin, cellulose and hemicellulose), and $m(g)$ is the weight of cassava residue or lignocellulosic components after incubation.

Cassava residue is a waste byproduct generated during cassava-based ethanol production, and it would be used as raw material for the pro- duction of methane or protein feed [1-4]. Therefore, lignin-degrading selectivity (LDS) was defined as the following equation (2). When LDS value of fungi is greater than 1.0, indicating that the fungi possess high lignin-degrading selectivity since they are prefer to degrade lignin.

$$
\text { LDS = lignin loss (\%) / weight loss (\%) }
$$

\section{Results}

3.1 Primary screening of lignin-degrading fungi

Using of guaiacol or azure B are rapid and reliable methods to screen lignin-degrading fungi because the structures of guaiacol and azure B resemble to lignin. Positive fungi showed red in guaiacol-containing plates or/and decolorization zones in azure B-containing plates $[18,19]$. In the present study, nineteen lignin-degrading fungi were screened out, two fungi had a positive reaction on both guaiacol and azure B plates, while six fungi had a positive reaction on guaiacol plate and eleven fungi had a positive reaction on azure $\mathrm{B}$ plate. Positively reacting fungus N1, N3, N5 and N8 were shown in Fig. (1) since the lignin-degrading selectivity of fungus N1 and N3 and degradation ability of fungus N5 and N8 was better than those of others which will be shown in following results.

\subsection{Characteristics of Fungal Decay Cassava Residue}

Table 1 showed weight losses, lignocellulosic components (cellulose, hemicellulose and lignin) losses, and LDS values of cassava residue which were decayed by nineteen screened fungi, P. chrysosporium and Trametes sp. SYBC-L4 in two weeks incubation. All tested fungi degraded amount of hemicellulose, and its losses were between $17.70 \%$ and $69.88 \%$. Lignin losses were between $0.97 \%$ and $25.10 \%$. Weight losses and cellulose losses were ranged from $7.45 \%$ to $29.09 \%$, and $7.38 \%$ to $64.32 \%$, respectively. The best degradation ability of tested fungi was $P$. chrysosporium, and the weight loss achieved by 29.09\%. Meanwhile, the best lignin-degrading selectivity of tested fungi was fungus N3, and the LDS value was 1.38 .

For a large number of samples, it is difficult to achieve comprehensive and concise conclusions through qualitative analysis above. Principal component analysis (PCA) is suitable for recognition and comparison of large numbers of samples, and visually displays the differences in ordination maps $[12,16]$. Therefore, the data in Table $\mathbf{1}$ were standardized and then analyzed by PCA, the results were shown in Table 2. The polynomial of the first principal component (PC1) and the five variables includ- 


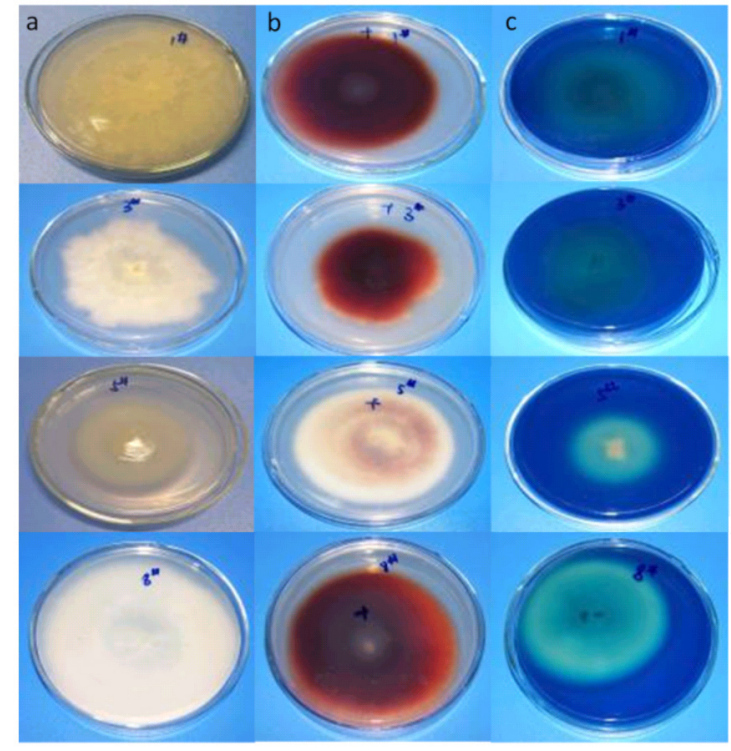

Fig. 1. Positively Reacting Fungus N1, N3, N5, N8 Cultured in Different Plates. ((a) PDA, (b) PDA Contained $400 \mathrm{mg} / \mathrm{L}$ Guaiacol, (c) PDA Contained $50 \mathrm{mg} / \mathrm{L}$ Azure B dye).

ing LDS value, weight loss, cellulose loss, hemicellulose loss, and lignin loss was calculated by the following equation (3). PC1 with a variance contribution of $58.76 \%$ showed a positive relationship with five variables, reflecting the degradation ability of fungi.

$$
\begin{gathered}
\text { PC1 }=0.55 \times \text { weight loss }+ \\
+0.50 \times \text { lignin loss }+0.51 \times \text { cellulose loss }+ \\
+0.35 \times \text { hemicellulose loss }+0.24 \times \operatorname{LDS}
\end{gathered}
$$

The polynomial of the second principal component (PC2) and the five variables were calculated by the following equation (4). PC2 with a variance contribution of $29.21 \%$ was negative in relation to weight loss, cellulose loss, and hemicellulose loss, but showed a positive relationship with lignin loss and LDS value, thus reflecting the fungal lignin-degrading selectivity.

$$
\begin{gathered}
\text { PC2 }=-0.20 \times \text { weight loss }+ \\
+0.42 \times \text { lignin loss }-0.24 \times \text { cellulose loss }- \\
-0.44 \times \text { hemicellulose loss }+0.73 \times \text { LDS }
\end{gathered}
$$

The variance contribution of two principal components (PC1 variance 58.76\% and PC2 variance $29.21 \%$ ) was $87.97 \%$, which meet the requirement of more than $85 \%$ [22]. The PCA biplot of two principal components showed the decay characteristics of fungi (Fig. 2). Four main groups can be discerned, set apart along the two component axes. Group A was located in the upper left quadrant, included fungus N1 and N3, which were high in lignin-degrading selectivity but poor in degradation ability. Group B, in the lower left quadrant, included fifteen fungi that were poor in both degradation

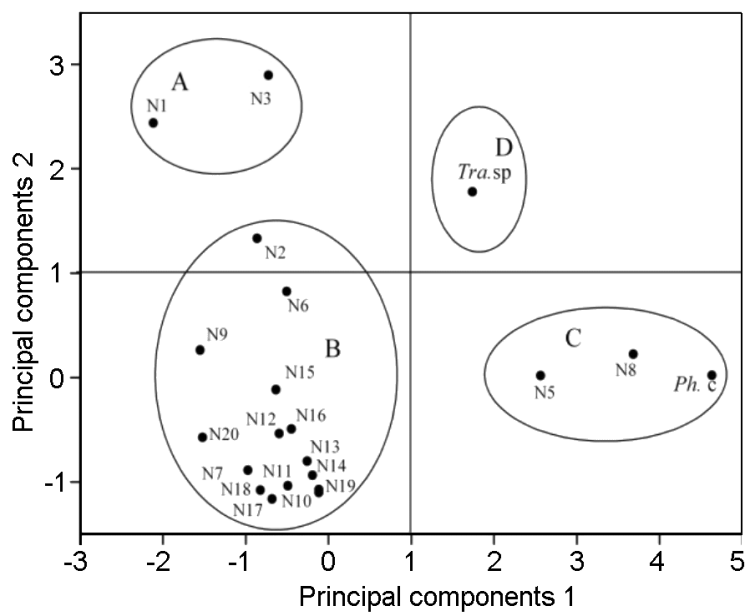

Fig. 2. PCA Plot from the Data of Weight loss, Components losses, and LDS value of Cassava Residue Decayed by Fungi.

ability and lignin-degrading selectivity. Group C included fungus N5 and N8, which were high in degradation ability but poor in lignin-degrading selectivity, and grouped with $P$. chrysosporium. Trametes sp. SYBC-L4 was in group $\mathrm{D}$ and exhibited a certain level of degradation ability and lignin-degrading selectivity.

\subsection{Cassava Residue Decayed by Iso- lated Fungi in Four Weeks Incubation}

Based on the PCA analysis above, fungus N1 and N3 showed lignin-degrading selectivity, while fungi N5 and N8 showed high degradation ability. To further investigate the degradation ability and lignin-degrading selectivity of these four fungi, cassava residue was decayed by these fungi for four weeks. Trametes sp. SYBC-L4 was selected to be compared with the four fungi because it simultaneously exhibited a certain level of degradation ability and lignin-degrading selectivity. The results of weight losses, components losses, and LDS value were shown in Table 3. In terms of selectivity, fungus N3 was better than other fungi, the LDS value of $\mathrm{N} 3$ ranged from 1.14 to 1.38 and was greater than that of other fungi. In terms of degradation ability, fungus $\mathrm{N} 5$ and $\mathrm{N} 8$ were better than others. Moreover, fungus N5 and N8 mainly decayed cassava residue in the first two weeks. To summarize, fungus N3, N5 and N8 were finally screened out on the basis of their characteristics of cassava residue decayed.

\subsection{Identification of the Isolated Fungi}

The 18S rDNA of the fungus N3, N5, and N8 were amplified by PCR and sequenced. As shown in Table 4, comparison of the $18 \mathrm{~S}$ rDNA sequences with data in the NCBI database indicated that the sequence of fungus N3 showed 99\% identity with Pleurotus sp., the sequence 
Bin Xu et al. / Screening of lignin-degrading fungi for ...

Table 1. Weight loss, components losses, and LDS of cassava residue decayed by lignin-degrading fungi after two weeks incubation

\begin{tabular}{|c|c|c|c|c|c|}
\hline Strain & Weight loss (\%) & Lignin Loss (\%) & Cellulose Loss (\%) & $\begin{array}{l}\text { Hemicellulose } \\
\text { Loss (\%) }\end{array}$ & LDS Value \\
\hline N1 & $7.45 \pm 0.64$ & $6.99 \pm 0.80$ & $9.21 \pm 0.51$ & $22.69 \pm 0.89$ & 0.94 \\
\hline $\mathrm{N} 2$ & $12.17 \pm 0.86$ & $7.63 \pm 0.40$ & $33.47 \pm 1.22$ & $19.48 \pm 0.25$ & 0.63 \\
\hline N3 & $9.65 \pm 0.48$ & $13.32 \pm 0.26$ & $7.38 \pm 0.47$ & $45.98 \pm 0.82$ & 1.38 \\
\hline Tra. sp & $20.18 \pm 0.42$ & $20.31 \pm 0.22$ & $39.61 \pm 0.99$ & $38.40 \pm 0.47$ & 1.01 \\
\hline N5 & $24.74 \pm 0.53$ & $17.18 \pm 0.27$ & $44.09 \pm 0.68$ & $62.88 \pm 0.40$ & 0.69 \\
\hline N6 & $16.45 \pm 0.74$ & $7.36 \pm 0.81$ & $35.50 \pm 0.43$ & $17.70 \pm 0.66$ & 0.45 \\
\hline N7 & $15.79 \pm 0.90$ & $1.18 \pm 0.28$ & $24.55 \pm 1.09$ & $47.64 \pm 1.62$ & 0.07 \\
\hline N8 & $28.10 \pm 0.82$ & $22.54 \pm 0.97$ & $52.35 \pm 0.54$ & $63.33 \pm 1.07$ & 0.80 \\
\hline N9 & $12.80 \pm 0.55$ & $3.27 \pm 0.89$ & $21.29 \pm 0.35$ & $30.72 \pm 0.40$ & 0.26 \\
\hline N10 & $16.70 \pm 0.94$ & $3.07 \pm 0.80$ & $31.26 \pm 1.04$ & $60.16 \pm 0.48$ & 0.18 \\
\hline N11 & $15.85 \pm 0.85$ & $1.72 \pm 0.59$ & $32.74 \pm 1.20$ & $50.98 \pm 0.48$ & 0.11 \\
\hline N12 & $15.75 \pm 0.56$ & $2.64 \pm 0.77$ & $35.44 \pm 0.24$ & $38.01 \pm 0.50$ & 0.17 \\
\hline N13 & $17.40 \pm 0.99$ & $2.89 \pm 0.52$ & $34.64 \pm 0.31$ & $45.82 \pm 1.08$ & 0.17 \\
\hline N14 & $15.86 \pm 0.64$ & $3.62 \pm 0.45$ & $29.29 \pm 0.10$ & $61.20 \pm 1.24$ & 0.23 \\
\hline N15 & $14.78 \pm 0.77$ & $4.65 \pm 0.64$ & $29.45 \pm 0.87$ & $41.63 \pm 0.26$ & 0.31 \\
\hline N16 & $17.24 \pm 0.75$ & $3.51 \pm 0.42$ & $32.11 \pm 1.03$ & $40.19 \pm 0.20$ & 0.20 \\
\hline N17 & $14.89 \pm 0.38$ & $1.19 \pm 0.67$ & $28.94 \pm 0.27$ & $56.09 \pm 0.20$ & 0.08 \\
\hline N18 & $14.72 \pm 0.64$ & $1.11 \pm 0.24$ & $27.77 \pm 0.17$ & $53.38 \pm 0.95$ & 0.07 \\
\hline N19 & $16.46 \pm 0.75$ & $3.24 \pm 0.60$ & $30.49 \pm 0.92$ & $61.62 \pm 0.64$ & 0.20 \\
\hline N20 & $12.11 \pm 0.66$ & $0.97 \pm 0.50$ & $23.51 \pm 0.21$ & $42.67 \pm 0.39$ & 0.08 \\
\hline$P h . c$ & $29.09 \pm 0.85$ & $25.10 \pm 0.72$ & $64.32 \pm 1.10$ & $69.88 \pm 0.40$ & 0.86 \\
\hline
\end{tabular}

Table 2. Eigenvalues of the Variables for Principal Components and Variance Explained by PCA

\begin{tabular}{|c|c|c|c|c|c||}
\hline Variables & $\begin{array}{c}\text { Principal Compo- } \\
\text { nent 1 (PC1) }\end{array}$ & PC2 & PC3 & PC4 & PC5 \\
\hline Weight loss & 0.55 & -0.20 & 0.18 & -0.69 & -0.39 \\
\hline Lignin loss & 0.50 & 0.42 & -0.02 & -0.14 & 0.74 \\
\hline Cellulose loss & 0.51 & -0.24 & 0.50 & 0.66 & -0.08 \\
\hline Hemicellulose loss & 0.35 & -0.44 & -0.81 & 0.19 & 0.03 \\
\hline LDS value & 0.24 & 0.73 & -0.26 & 0.21 & -0.54 \\
\hline Variance explained (\%) & 58.76 & 29.21 & 11.11 & 0.74 & 0.18 \\
\hline
\end{tabular}

of fungus N5 showed 99\% identity with Trametes sp., and the sequence of fungus N8 showed 99\% identity with Coriolopsis sp. The identified species are both white rot fungi, which produce ligninolytic enzymes including laccase and manganese peroxidase $(\mathrm{MnP})$, but no lignin peroxidase $(\mathrm{LiP})$ [23-25].

\section{Discussions}

At present, cassava residue is mainly used as raw material to produce methane or protein feed [1-4]. Methane is produced by anaerobic digestion including three steps: hydrolysis, acidogenesis and methanogenesis [1]. Protein feed is produced by co-culturing of fungi and yeast, supplying a certain amount of inorganic nitrogen under solid state fermentation [4]. Bioconversion efficiency of cassava residue by anaerobic digestion or co-culturing of fungi and yeast is low due to the recalcitrant lignocellulose structure of cassava residue, in particular the lignin since it is a cross-linked hydrophobic polymer that is fairly resistant to degradation [5]. Therefore, isolation and characterization of lignin-degrading fungi to decay cassava residue is favorable for bioconversion of cassava residue. Moreover, fungi with high lignin-degrad- 
Bin Xu et al. / Screening of lignin-degrading fungi for ...

Table 3. Weight loss, Components losses, and LDS of Cassava Residue Decayed by the Isolates during Four Weeks Incubation

\begin{tabular}{|c|c|c|c|c|c|c|}
\hline Strain & Weeks & Weight Loss (\%) & Lignin Loss (\%) & $\begin{array}{c}\text { Cellulose Loss } \\
(\%)\end{array}$ & $\begin{array}{l}\text { Hemicellulose } \\
\text { Loss (\%) }\end{array}$ & $\begin{array}{l}\text { LDS } \\
\text { Value }\end{array}$ \\
\hline \multirow{4}{*}{ N1 } & 1 & $3.37 \pm 0.52$ & $3.18 \pm 0.23$ & $3.44 \pm 0.60$ & $13.39 \pm 0.17$ & 0.94 \\
\hline & 2 & $7.45 \pm 0.64$ & $6.99 \pm 0.80$ & $9.21 \pm 0.51$ & $22.69 \pm 0.89$ & 0.94 \\
\hline & 3 & $11.22 \pm 0.31$ & $8.56 \pm 0.27$ & $18.05 \pm 0.49$ & $28.04 \pm 0.14$ & 0.76 \\
\hline & 4 & $15.06 \pm 0.80$ & $11.89 \pm 0.81$ & $27.8 \pm 0.61$ & $32.17 \pm 0.92$ & 0.79 \\
\hline \multirow{4}{*}{ N3 } & 1 & $8.61 \pm 0.64$ & $10.57 \pm 0.70$ & $7.14 \pm 0.51$ & $31.31 \pm 0.65$ & 1.23 \\
\hline & 2 & $9.65 \pm 0.48$ & $13.32 \pm 0.26$ & $7.38 \pm 0.47$ & $45.98 \pm 0.82$ & 1.38 \\
\hline & 3 & $12.54 \pm 0.59$ & $14.23 \pm 0.44$ & $10.25 \pm 0.87$ & $62.77 \pm 0.72$ & 1.14 \\
\hline & 4 & $16.23 \pm 0.84$ & $18.89 \pm 0.20$ & $16.12 \pm 0.98$ & $63.48 \pm 1.03$ & 1.16 \\
\hline \multirow{4}{*}{$\begin{array}{l}\text { Trametes sp. } \\
\text { SYBC-L4 }\end{array}$} & 1 & $16.50 \pm 0.80$ & $11.23 \pm 0.99$ & $31.22 \pm 0.41$ & $30.4 \pm 1.01$ & 0.68 \\
\hline & 2 & $20.18 \pm 0.42$ & $20.31 \pm 0.22$ & $39.61 \pm 0.99$ & $38.4 \pm 0.47$ & 1.01 \\
\hline & 3 & $23.02 \pm 0.88$ & $23.96 \pm 0.76$ & $45.18 \pm 1.33$ & $40.31 \pm 0.63$ & 1.04 \\
\hline & 4 & $25.28 \pm 0.97$ & $25.82 \pm 0.96$ & $48.28 \pm 1.27$ & $45.96 \pm 0.51$ & 1.02 \\
\hline \multirow{4}{*}{ N5 } & 1 & $19.96 \pm 0.83$ & $13.06 \pm 0.50$ & $38.03 \pm 1.10$ & $58.8 \pm 0.80$ & 0.65 \\
\hline & 2 & $24.74 \pm 0.53$ & $17.18 \pm 0.27$ & $44.09 \pm 0.68$ & $62.88 \pm 0.40$ & 0.69 \\
\hline & 3 & $27.12 \pm 0.68$ & $26.12 \pm 1.00$ & $50.32 \pm 0.40$ & $68.19 \pm 0.37$ & 0.96 \\
\hline & 4 & $30.93 \pm 0.97$ & $30.54 \pm 0.84$ & $54.47 \pm 1.05$ & $70.64 \pm 1.14$ & 0.98 \\
\hline \multirow{4}{*}{ N8 } & 1 & $22.78 \pm 0.50$ & $16.56 \pm 0.67$ & $40.3 \pm 0.48$ & $60.29 \pm 0.56$ & 0.73 \\
\hline & 2 & $28.10 \pm 0.82$ & $22.54 \pm 0.97$ & $52.35 \pm 0.54$ & $63.33 \pm 1.07$ & 0.80 \\
\hline & 3 & $31.70 \pm 0.77$ & $25.49 \pm 0.62$ & $55.77 \pm 1.05$ & $67.16 \pm 0.70$ & 0.80 \\
\hline & 4 & $33.34 \pm 0.98$ & $27.66 \pm 0.90$ & $56.95 \pm 1.04$ & $70.99 \pm 1.16$ & 0.83 \\
\hline
\end{tabular}

ing selectivity and/or degradation ability are preferred. Fungi with high lignin-degrading selectivity have been proved to enhance methane production from lignocellulosic biomass [5,7,9]. Fungi with high degradation ability decay lignocellulosic biomass rapidly and throughly to enhance yeast production for improvement of protein content and palatability of feed [2]. In the present investigation of cassava residue decayed, fungus N3 showed high lignin-degrading selectivity and fungus N5 and N8 showed high degradation ability. These fungi would facilitate the decomposing of cassava residue to enhance production of methane or protein feed.

The three fungus N3, N5 and N8 screened out were identified as Pleurotus sp., Trametes sp. and Coriolopsis sp. respectively. Pleurotus sp. has shown high lignin-degrading selectivity in different types of lignocellulosic biomass decayed and has been used to enhance methane production [9,24]. Müller and Trösch [9] concluded that Pleurotus florida showed the fastest delignification among twenty-two tested fungi. Wheat straw pretreated by this fungus was fermented anaerobically to biogas, and the gas yield was twice the amount of the untreated straw. The screened fungus N3, a Pleurotus sp. in the present study, also showed high lignin-degrading selectivity in cassava residue decayed with a maximum LDS value of 1.38 , suggesting that fungus N3 is useful for enhancing methane production from cassava residue. Trametes sp. generally shows no lignin-degrading selectivity but good degradation ability in lignocellulosic biomass decayed [9,12] and has been found to produce protein feed from lignocellulosic biomass. JalC et al. [26] reported that Trametes gibbosa incubated on wheat straw could significantly improve the crude protein content and in vitro dry matter digestibility. Zhu et al. [25] concluded that Trametes versicolor has potential for laccase production using solid state fermentation, as well as the simultaneous improvement of the crude protein content in corn stover. Coriolopsis sp. secrete extracellular oxidase laccase, and have been used to eliminate toxic waste, e.g. nonylphenol, bisphenol A, triclosan, and azo dyes, but have rarely been used to decay lignocellulosic biomass[23]. The screened fungus N5 and N8 were Trametes sp. and Coriolopsis sp., respectively. They both showed high degradation ability in cassava residue decayed, and grouped with $P$. chrysosporium, a typical white rot fungus with high degradation ability [11]. Decayed characteristics of fungus N5 and N8 suggesting that they are favorable of protein feed production from cassava residue.

PCA was an effective method of identifying lignocellulosic biomass decay characteristics 
Bin Xu et al. / Screening of lignin-degrading fungi for ...

Table 4. Identification of the Fungal Isolates by $18 \mathrm{~S}$ rDNA Gene Sequencing

\begin{tabular}{|c|c|c|}
\hline Fungi & Accession Number & Sequence Identity \\
\hline $\mathrm{N} 3^{\mathrm{a}}$ & KC422248 & - \\
\hline Pleurotus cystidiosus strain P-24 ${ }^{\text {b }}$ & FJ379283.1 & $99 \%$ \\
\hline Pleurotus cornucopiae strain P-38 ${ }^{\mathrm{b}}$ & FJ869181.1 & $99 \%$ \\
\hline Pleurotus ostreatus strain $\mathrm{Po}-13^{\mathrm{b}}$ & FJ379284.1 & $99 \%$ \\
\hline Pleurotus ostreatus AFTOL-ID $564^{\text {b }}$ & AY657015.1 & $99 \%$ \\
\hline N5 ${ }^{a}$ & KC422247 & - \\
\hline Trametes sp. CPCC $480671^{\mathrm{b}}$ & FJ515315.1 & $99 \%$ \\
\hline Trametes hirsute ${ }^{\mathrm{b}}$ & $\mathrm{AB} 084607.1$ & $99 \%$ \\
\hline Trametes versicolor strain BCRC $36387^{\text {b }}$ & AY309019.1 & $99 \%$ \\
\hline Trametes versicolor strain ATCC $11235^{\mathrm{b}}$ & AY309018.1 & $99 \%$ \\
\hline N8 ${ }^{a}$ & KC422249 & - \\
\hline Coriolopsis gallica strain RLG 7630-SP b & AY336772.1 & $99 \%$ \\
\hline Coriolopsis byrsina strain CRM- $46^{\text {b }}$ & AY336773.1 & $99 \%$ \\
\hline Coriolopsis polyzona strain $\mathrm{OH}-184-\mathrm{SP}^{\mathrm{b}}$ & AY336771.1 & $99 \%$ \\
\hline Coriolopsis byrsina ${ }^{\mathrm{b}}$ & JN546141.1 & $99 \%$ \\
\hline
\end{tabular}

a The isolates submitted to the National Center for Biotechnology Information (NCBI) GenBank .

b Strains chosen from the National Center for Biotechnology Information (NCBI) GenBank database.

instead of electron microscopy, cytochemistry and conventional chemical analysis. Ferraz et al. [12] used PCA to identify and group eight basidiomycetes and two ascomycetes cultured on Eucalyptus grandis wood. The results showed that PCA was very efficient in recognizing wood decay characteristics. Yu [14] used PCA to recognize the characteristics of fortynine fungi in Moso bamboo decayed, the results showed that PCA was a useful tool for analyzing large weight and components losses dataset. In this study, PCA was used to favor fungal screening for cassava residue decayed. Based on the results of PCA, twenty-one fungi were placed in four groups, and their decay characteristics displayed visually in ordination maps (Fig. 2).As a consequence, fungus N3 with high lignin-degrading selectivity and fungus N5 and N8 with high degradation ability were screened out conveniently.

\section{Conclusions}

Principal component analysis was applied successfully to recognize the characteristics of fungal decay in cassava residue, and is helpful of screening fungi for their potential applications. Three lignin-degrading fungi were screened out for cassava residue decayed. Fungus N3, a Pleurotus sp. exhibited high lignindegrading selectivity. Fungus N5 and N8 were Trametes sp.and Coriolopsis sp., respectively, which exhibited high degradation ability. The three screened fungi possess potential application in the bioconversion of cassava residue to added value products.

\section{Acknowledgements}

This work is financially supported by Key Technology Program of Henan Province (No. 152102110156)

\section{References}

1. Q. H. Zhang, et al., Bioresour Technol, 102, 8899, 2011.

2. Y. H. Tang, B. F. Xie, Pharm Biotechn, 13, 51, 2006.

3. A. O. Ubalua, Afr J Microbiol Res, 18, 2065, 2007.

4. C. Liu, M.S. thesis, Central China Agricultural University, Wuhan, China, 2009.

5. F. Monlau, A. Barakat, E. Trably, et al Crit Rev Env Sci Tec, 43, 260, 2013.

6. C. Sánchez, Biotechnol Adv, 27, 185, 2009.

7. R. Amirta, T. Tanabe, T. Watanabe, Y. Honda, et al, J Biotechnol, 123, 71, 2006.

8. A. J. Chang, J. Fan, X. Wen, Int Biodeterior Biodegr, 72, 26, 2012.

9. H. Müller, W. Trösch, Appl Microbiol Biot, 24, 180, 1986.

10. L. Zhao, et al., Bioresour Techn, vol. 114, pp. 365-369, June 2012.

11. C. Wan, and Y. Li, Biotechnol Advanc, 30, 1447, 2012.

12. A. Ferraz, E. Esposito, R. E. Bruns, N. Durán, World J Microbiol Biotechn, 14,. 487, 1998.

13. E. Agosin, et al., Appl Environment Microbiol, 56, 65, 1990.

14. H. B. Yu, "Studies on degradation difference of three kinds of lignocellulose with white rot fun- 
gi," Ph. D. dissertation, Huazhong University of Science and Technology, Wuhan, China, 2007.

15. K. Fackler, M. Schwanninger, C. Gradinger, et al., Holzforschung, 61, 680, 2007.

16. A. Ferraz, J. Rodriguez, J. Freer, J. Baeza, World J Microbiol Biotechn, 17, 31, 2001.

17. J. Šnajdr, et al., FEMS Microbiol Ecol,. 78, 80, 2011.

18. M. I. Ali, N. M. Khalil, M. N. A. El-Ghany, Afr $J$ Microbiol Res, 16, 3783, 2012.

19. H. Y. Chen, D. S. Xue, X. Y. Feng, S. J. Yao, Appl J Biochem Biotechnol, 165, 1754, 2011.

20. M. J. Dinis, et al., Bioresour Technol, 100, 4829, 2009.
21. M. Yu, G. M. Zeng, Y. N. Chen, H. Y. Yu, et al., Process Biochem, 44, 17, 2009.

22. X. Q. He, Multivariate statistical analysis, China Renmin University Press, Beijing, 2008, pp. 153-173.

23. H. Cabana, et al., Chemosphere, 67, 770, 2007.

24. T. K. Hakala, P. Maijala, J. Konn, A. Hatakka, Enzyme Microb Tech, 34, 255, 2004.

25. Y. Zhu, H. Zhang, Y. Zhang, F. Huang, Afr J Microbiol Res, 45, 9182, 2011.

26. D. Jalč, F. Nerud, R. Žitňan, and P. Siroka, Folia Microbiol, 41, 73, 1996. 